\title{
Molecular characterization and population structure study of cambuci: strategy for conservation and genetic improvement
}

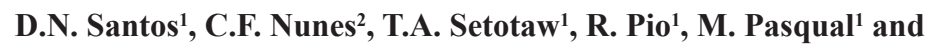 \\ G.M.A. Cançado ${ }^{3}$ \\ ${ }^{1}$ Departamento de Agricultura, Universidade Federal de Lavras, Lavras, MG, \\ Brasil \\ ${ }^{2}$ Instituto de Ciências Agrárias, Universidade Federal de Minas Gerais, \\ Montes Claros, MG, Brasil \\ ${ }^{3}$ Unidade Mista de Pesquisa em Genômica Aplicada a Mudanças Climáticas, \\ Empresa Brasileira de Pesquisa Agropecuária, Campinas, SP, Brasil \\ Corresponding author: D.N. Santos \\ E-mail: dalilhians@gmail.com
}

Genet. Mol. Res. 15 (4): gmr15049134

Received September 2, 2016

Accepted October 24, 2016

Published December 19, 2016

DOI http://dx.doi.org/10.4238/gmr15049134

Copyright $(C 2016$ The Authors. This is an open-access article distributed under the terms of the Creative Commons Attribution ShareAlike (CC BY-SA) 4.0 License.

\begin{abstract}
Cambuci (Campomanesia phaea) belongs to the Myrtaceae family and is native to the Atlantic Forest of Brazil. It has ecological and social appeal but is exposed to problems associated with environmental degradation and expansion of agricultural activities in the region. Comprehensive studies on this species are rare, making its conservation and genetic improvement difficult. Thus, it is important to develop research activities to understand the current situation of the species as well as to make recommendations for its conservation and use. This study was performed to characterize the cambuci accessions found in the germplasm bank of Coordenadoria de Assistência Técnica
\end{abstract}


Integral using inter-simple sequence repeat markers, with the goal of understanding the plant's population structure. The results showed the existence of some level of genetic diversity among the cambuci accessions that could be exploited for the genetic improvement of the species. Principal coordinate analysis and discriminant analysis clustered the 80 accessions into three groups, whereas Bayesian modelbased clustering analysis clustered them into two groups. The formation of two cluster groups and the high membership coefficients within the groups pointed out the importance of further collection to cover more areas and more genetic variability within the species. The study also showed the lack of conservation activities; therefore, more attention from the appropriate organizations is needed to plan and implement natural and ex situ conservation activities.

Key words: Campomanesia phaea; Cambuci; Germoplasm Bank; ISSR; Multivariate analysis; Atlantic rainforest

\section{INTRODUCTION}

The Atlantic Forest contains $35 \%$ of the plant species in Brazil, comprising approximately 20,000 species, but this biome is being degraded and requires conservation. According to the Ministry of Environment (2016), the biodiversity of the Atlantic Forest is higher than that of some entire continents, including North America $(17,000)$ and Europe $(12,500)$; for this reason, the Atlantic Forest is the highest priority for conservation of world biodiversity. The biodiversity of this forest includes Campomanesia phaea, commonly known as cambuci in Brazil.

Botanically, cambuci belongs to the Myrtaceae family. It is a semi-deciduous plant that can reach 4 to $10 \mathrm{~m}$ in height. The leaves are simple, sub-leathery, glabrous, and shiny on the upper surface. It has isolated axillary flowers formed from August to November that produce fruits in the shape of unidentified flying objects (UFOs) (Figure 1). The fruits mature from January to April and show green color even under these conditions. The fruit has ecological importance due to its contribution as food for wild animals (Kawasaki and Landrum, 1997; Lorenzi et al., 2006).

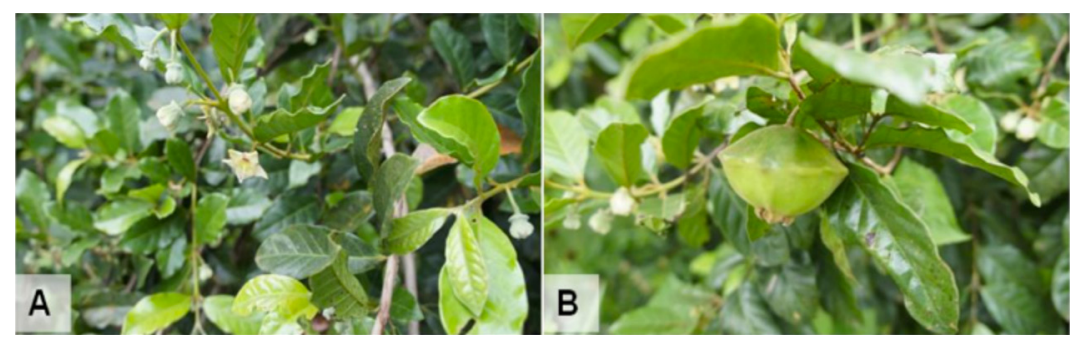

Figure 1. Cambuci (Campomanesia phaea): A. Leaves and flowers; B. Disk-shaped fruit.

Cambuci can be consumed in its natural form or processed as a juice, jelly, or candy. It is also used as an ornamental plant due to the delicate form of its canopy and the exotic nature of the fruit. The only prior study of the fruits revealed a high content of soluble solids and high acidity (Bianchini et al., 2016).

Genetics and Molecular Research 15 (4): gmr15049134 
Despite their importance, wild species are suffering a loss of genetic diversity because of urbanization and agricultural expansion (Johansson et al., 2007; Calaça and Dias, 2010), and the same is true for cambuci. Although cambuci is an important crop species, research reports on the species are rare. There is little scientific information available to develop conservation activities, sustainable management, and improvement plans for the species (Danner et al., 2011). This highlights the importance of developing research activities to provide scientific information to the appropriate organizations.

Therefore, the genetic characterization of cambuci is urgently needed. To begin with, the collections found in the germplasm banks should be used. The only germplasm bank for the species is maintained by Coordenadoria de Assistência Técnica Integral (CATI), which is located in the town of São Bento do Sapucaí in the State of São Paulo, Brazil. This collection contains accessions collected from Serra do Mar and Serra da Mantiqueira, the mountainous areas that together occupy an important region of Southeast and South Brazil. According to Carnaval et al. (2009), Serra do Mar concentrates the greatest genetic wealth and is considered an important center of biodiversity (Aguiar et al., 2003). Serra da Mantiqueira also has tremendous importance in relation to biodiversity and is considered the eighth most irreplaceable protected area in the world, based on a study done by the International Union for Conservation of Nature (IUCN) (Le Saout et al., 2014).

Among the tools that could be used to study genetic characterizations are molecular markers. Molecular markers are based on the plant genome and permit fast, high-quality characterization on a large scale (Varshney et al., 2005). Molecular markers have an advantage over morphological markers in that they are not affected by environmental factors and are more stable (Basha and Sujatha, 2007).

Among the molecular markers available, the inter-simple sequence repeat (ISSR) is a dominant multilocus interspecific and does not require prior knowledge about the DNA sequence of the plant species under consideration. Therefore, ISSRs are adequate to study the genetic diversity of wild species like cambuci.

There are some reports on the use of the ISSR molecular marker in the Myrtaceae family. Lima et al. (2015) used it to study the genetic structure of five species of this family, including Myrcia laruotteana, Myrcia selloi, Myrcia lajeana, and Myrcia tomentosa. Cheong and Ranghoo-Sanmukhiya (2013) used morphological and ISSR markers in Myrtaceae to study the phylogeny of the genus Syzygium, and observed that Syzygium samarangense is not closely related to other species studied. The ISSR marker has also been used to study genetic diversity in other fruit crop species. Reyes-Alemán et al. (2016) used the ISSR marker to study the genetic relationships within the Persea genus. Jimenez et al. (2015) performed genetic diversity analysis of Brazilian Hancornia speciosa Gomes using ISSR markers. Moraes Filho et al. (2015) used the ISSR marker to investigate the genetic diversity of Metrodorea nigra St. Hill from the Brazilian Atlantic Forest. All these findings demonstrated the efficiency of the ISSR marker for studying the population structure and genetic diversity of wild species.

To our knowledge, there is little information about the genetic structure of cambuci; therefore, this type of research is needed in order to generate information that can aid organizations develop appropriate conservation and breeding strategies for cambuci and consequently benefit the local community.

Therefore, we conducted this study with the objective of examining the population structure and genetic diversity of the cambuci accessions collected from Serra do Mar and Serra da Mantiqueira that are maintained at the germplasm bank of CATI using ISSR markers as well as generating knowledge to aid in the conservation and genetic improvement of the species.

Genetics and Molecular Research 15 (4): gmr15049134 


\section{MATERIAL AND METHODS}

\section{Plant materials}

The Cambuci accessions used in this study were obtained from the seedling production center of CATI, located in São Bento do Sapucaí in the State of São Paulo. The municipality is located in the micro-region of Campos do Jordão in Serra da Mantiqueira, within a latitude of $22^{\circ} 41^{\prime} 20^{\prime}$ 'S, longitude of $45^{\circ} 43^{\prime} 51^{\prime \prime} \mathrm{W}$, and altitude of $886 \mathrm{~m}$.a.s.l. The center has a subtropical climate with a mean rainfall between 1600 to $1800 \mathrm{~mm}$, relative humidity of $65 \%$, and mean annual temperature between $12^{\circ}$ and $18^{\circ} \mathrm{C}$, that reaches $0^{\circ} \mathrm{C}$ in winter.

The collection was established from accessions obtained from different parts of the Atlantic Forest in the regions of Serra do Mar within a latitude of $26^{\circ} 0^{\prime} 0^{\prime \prime} \mathrm{S}$ and longitude $48^{\circ} 57^{\prime} 0^{\prime \prime} \mathrm{W}$ and the Serra da Mantiqueira within a latitude of $22^{\circ} 28^{\prime} 5^{\prime \prime} \mathrm{S}$ and longitude $45^{\circ} 0^{\prime} 12^{\prime \prime} \mathrm{W}$. Eighty accessions sampled from the 140 accessions found in the germplasm bank were included in this study. The other 60 accessions were excluded because they either lacked sufficient leaf samples for the extraction of DNA or the DNA extraction method we used did not produce the required concentration. The numbers and descriptions of the accessions are listed in Table 1.

Table 1. Cambuci accessions (Campomanesia phaea) evaluated in this study with identification (ID) and accession numbers.

\begin{tabular}{l|c|l|c|l|c|c|c}
\hline ID & Accession No. & ID & Accession No. & ID & Accession No. & ID & Accession No. \\
\hline 1 & 7201 & 21 & 7227 & 41 & 7260 & 61 & 7285 \\
\hline 2 & 7202 & 22 & 7228 & 42 & 7261 & 62 & 7286 \\
\hline 3 & 7203 & 23 & 7229 & 43 & 7262 & 63 & 7287 \\
\hline 4 & 7204 & 24 & 7230 & 44 & 7264 & 64 & 7888 \\
\hline 5 & 7205 & 25 & 7236 & 45 & 7265 & 65 & 7291 \\
\hline 7 & 7206 & 26 & 7238 & 46 & 7266 & 66 & 7292 \\
\hline 8 & 7207 & 27 & 7239 & 47 & 7267 & 67 & 7293 \\
\hline 9 & 7209 & 28 & 7242 & 49 & 7268 & 68 & 7294 \\
\hline 11 & 7210 & 29 & 7243 & 50 & 7269 & 69 & 7295 \\
\hline 12 & 7211 & 30 & 7245 & 51 & 7272 & 71 & \\
\hline 13 & 7214 & 31 & 7246 & 52 & 7273 & 72 & 7298 \\
\hline 15 & 7216 & 32 & 7247 & 53 & 7274 & 73 & 7299 \\
\hline 16 & 7217 & 33 & 7249 & 54 & 7275 & 74 & 72303 \\
\hline 18 & 7218 & 34 & 7252 & 55 & 7276 & 75 & 72304 \\
\hline 19 & 7220 & 35 & 7254 & 56 & 7277 & 76 & 72306 \\
\hline 20 & 7221 & 36 & 7255 & 58 & 7278 & 77 & 72307 \\
\hline
\end{tabular}

\section{DNA extraction}

To extract the genomic DNA, young leaves were collected and packed in paper bags with identification. The leaves were transported to the laboratory and stored in a deep freezer at $-80^{\circ} \mathrm{C}$ until DNA extraction. Genomic DNA was extracted according to the method developed by Nunes et al. (2011). To verify the quality of the DNA, electrophoresis of sample DNA was performed on a $0.7 \%$ agarose gel with the addition of ethidium bromide $(0.3 \mathrm{mg} / \mathrm{mL})$, and the results were visualized under UV light using a Vetec photo documenter. The DNA was

Genetics and Molecular Research 15 (4): gmr15049134 
quantified based on the reading at $260 \mathrm{~nm}$ absorbance using a UV/VIS spectrophotometer. In the same sample, a reading at $280 \mathrm{~nm}$ was performed, and the ratio of the readings at 260/280 $\mathrm{nm}$ was used to verify the quality of the DNA. The samples with a 1.5 to 2 ratio were used for genotyping analysis using ISSR markers.

\section{ISSR molecular marker analysis}

As the literature does not report ISSR markers that are polymorphic for cambuci, we used ISSR markers described as polymorphic in other fruit crop species, such as Vitis spp (Moreno et al., 1998; Dhanorkar et al., 2005; Alizadeh et al., 2008), Olea europaea (MartinsLopes et al., 2007), and Citrullus lanatus (Amnon et al., 2004). The motifs, descriptions, and sequences of the 13 ISSR markers are presented in Table 2.

Table 2. Names, sequences, annealing temperatures, and references of the ISSR primers used to characterize the cambuci (Campomanesia phaea) accessions.

\begin{tabular}{|c|c|c|c|c|}
\hline Name & Primer sequence $\left(5^{\prime}-3^{\prime}\right)$ & Motif & $\mathrm{T}\left({ }^{\circ} \mathrm{C}\right)$ & Reference \\
\hline UBC 809 & GAGGAGAGAGAGAGAGG & $(\mathrm{GA})_{7} \mathrm{G}$ & 54 & Amnon et al., 2004 \\
\hline UBC810 & GAGAGAGAGAGAGAGAT & $(\mathrm{GA})_{8} \mathrm{~T}$ & 52 & Martins-Lopes et al., 2007 \\
\hline UBC812 & GAGAGAGAGAGAGAGAA & $(\mathrm{GA})_{8} \mathrm{~A}$ & 51.6 & Alizadeh et al., 2008 \\
\hline UBC 817 & CACACACACACACACAA & $(\mathrm{CA})_{8} \mathrm{~A}$ & 54 & Amnon et al., 2004 \\
\hline UBC 823 & TCTCTCTCTCTCTCTCC & $(\mathrm{TC})_{8} \mathrm{C}$ & 54 & Amnon et al., 2004 \\
\hline UBC827 & ACACACACACACACACG & $(\mathrm{AC})_{8} \mathrm{G}$ & 50 & Casu et al., 2005 \\
\hline UBC 849 & GTGTGTGTGTGTGTGTCTA & $(\mathrm{GT})_{8} \mathrm{CTA}$ & 54 & Amnon et al., 2004 \\
\hline UBC850 & GTGTGTGTGTGTGTGTYC & $(\mathrm{GT})_{8} \mathrm{YC}$ & 52 & Moreno et al., 1998 \\
\hline UBC855 & ACACACACACACACACYT & $(\mathrm{AC})_{8} \mathrm{YT}$ & 52 & Dhanorkar et al., 2005 \\
\hline UBC856 & ACACACACACACACACYA & $(\mathrm{AC})_{8} \mathrm{YA}$ & 48 & Nascimento et al., 2010 \\
\hline UBC857 & ACACACACACACACACYG & (AC) $8 \mathrm{YG}$ & 52 & Moreno et al., 1998 \\
\hline UBC890 & VHV GTGTGTGTGTGTGTT & $\mathrm{VHV}(\mathrm{GT})_{7} \mathrm{~T}$ & 52 & Moreno et al., 1998 \\
\hline UBC891 & HVH TGTGTGTGTGTGTG & $\mathrm{HVH}(\mathrm{TG})_{7}$ & 52 & Moreno et al., 1998 \\
\hline
\end{tabular}

The reaction was realized in a final volume of $25 \mu \mathrm{L}$ containing $50 \mathrm{ng}$ DNA, $7.5 \mu \mathrm{L}$ $5 \mathrm{X}$ reaction buffer, $1.5 \mathrm{mM} \mathrm{MgCl}, 200 \mu \mathrm{M}$ of each dNTP, $0.8 \mu \mathrm{M}$ primer (Sigma, USA), and 2.4 U Taq DNA polymerase (Go Taq Flexi, Promega, USA). PCR was performed using a gradient thermocycler (Multigene Gradient, Labnet International, USA) programed with an initial denaturation of $2 \mathrm{~min}$ at $95^{\circ} \mathrm{C}$ followed by 40 cycles of denaturation at $95^{\circ} \mathrm{C}$ for $45 \mathrm{~s}$ with a variable annealing temperature for $1 \mathrm{~min}$, depending on the primer, and primer extension at $72^{\circ} \mathrm{C}$ for $2 \mathrm{~min}$. The final extension was realized at $72^{\circ} \mathrm{C}$ for $5 \mathrm{~min}$. For each primer, two independent amplifications were performed to test the reproducibility of the primers.

The amplified product was submitted to electrophoresis on a $1.5 \%$ agarose gel with the addition of ethidium bromide $(0.3 \mathrm{mg} / \mathrm{mL})$, immersed in $1 \mathrm{X}$ TBE buffer for $4 \mathrm{~h}$ under a voltage of $110 \mathrm{~V}$, and subsequently photographed using a Vetec photo documenter equipped with a UV light detector.

\section{Statistical analysis}

The PCR product of each ISSR primer was codified in a binary matrix with 0 as the absence of the band and 1 as the presence of the band and subjected to further statistical analysis. To understand the efficiency of each ISSR primer, the number of polymorphic bands (NPB), polymorphic information content (PIC), and mean resolving power (MRP)

Genetics and Molecular Research 15 (4): gmr15049134 
were estimated according to Anderson et al. (1993) and Kayis et al. (2010). In addition, the heterozygosity $(\mathrm{H})$ and Shannon Information Index were estimated for the populations using the PopGen software (Yeh and Boyle, 1997).

To understand the population structure of the cambuci accessions in a twodimensional graph, principal coordinate analysis (PCoA) was performed using GeneAlex version 6.5.2 (Peakall and Smouse, 2006). In addition, the R package adegenet DAPC (Jombart, 2008) was employed to perform discriminant analysis among cambuci accessions based on the ISSR marker data.

Bayesian model-based clustering analysis for the 80 accessions was carried out using the Structure 3.4.3 software (Pritchard et al., 2000) with 10,000 burn-in and 100,000 Markov Chain Monte Carlo iterations for the admixture, and allele-correlated models were employed for $\mathrm{k}=1$ to $10(\mathrm{~K}=$ groups numbers formed according to the Structure software). Finally, the output from this result was subjected to Structure Harvester (Earl and vonHoldt 2012) to determine the appropriate number of clusters according to the method proposed by Evanno et al. (2005).

\section{RESULTS}

\section{ISSR molecular marker analysis}

The 13 ISSR markers used to study the genetic diversity and population structure of the cambuci accessions produced 82 polymorphic bands, with an average of 6.3 bands per primer. The estimated value of PIC for the 13 primers was higher for primers UBC $850(0.476)$ and UBC $856(0.455)$ and lower for UBC 827 (0.362) (Table 3). With the exceptions of UBC 823,827 , and 849 , the primers all exhibited a high PIC value that demonstrated their efficiency in discriminating the cambuci accessions in this study.

Table 3. Genetic parameters of 13 ISSR markers, including polymorphic information content (PIC), mean resolving power (MRP), and number of polymorphic bands (NPB), used to genotype the 80 accessions of cambuci (Campomanesia phaea).

\begin{tabular}{l|c|c|c}
\hline Marker & PIC & MRP & NPB \\
\hline UBC809 & 0.436 & 0.697 & 9 \\
\hline UBC810 & 0.434 & 0.700 & 8 \\
\hline UBC812 & 0.423 & 0.653 & 8 \\
\hline UBC817 & 0.413 & 0.619 & 6 \\
\hline UBC823 & 0.381 & 0.533 & 7 \\
\hline UBC827 & 0.362 & 0.493 & 7 \\
\hline UBC849 & 0.363 & 0.550 & 4 \\
\hline UBC855 & 0.476 & 0.825 & 5 \\
\hline UBC856 & 0.454 & 0.775 & 7 \\
\hline UBC857 & 0.455 & 0.755 & 5 \\
\hline UBC891 & 0.439 & 0.707 & 6 \\
\hline
\end{tabular}

NPBs produced per primer ranged from four (UBC 810 and UBC 850) to nine (UBC 809) (Table 3). There was no strong correlation between the PIC value and the NPB, since primer UBC 850, which had the lowest NPB, produced the highest PIC (Table 3).

The ISSR primers with high PIC values also had high MRP (Table 3), suggesting a strong positive correlation between these parameters. Primer UBC 850, which had a high PIC

Genetics and Molecular Research 15 (4): gmr15049134 
value (0.476), also showed high mean resolving power, indicating that this primer was more efficient at discriminating the cambuci accessions in this study. The MRP is the parameter that indicates the efficiency of a primer at discriminating the samples under observation and can be used as a selection criterion for efficient primers to use in studying the genetic diversity of a given species. In this study, primer UBC 850 was most efficient at differentiating and clustering the cambuci accessions into groups. In addition, ISSR primers UBC810, UBC 856, UBC 857, and UBC 890 produced higher MRP (Table 3) than the others, indicating that these primers can also be considered efficient for studying the genetic diversity of cambuci accessions. The strong and significant positive correlation between the PIC values and MRP of the primers $(\mathrm{r}=0.979)$ indicates that one of these parameters can be used to select primers with

discriminating capacity in future studies. The regression analysis of the PIC and MRP values confirmed this significant and strong positive relationship between them, with $\mathrm{R}^{2}=0.956$.

\section{Genetic diversity and population structure analysis among cambuci accessions}

PCoA was employed to elucidate the genetic diversity patterns of the cambuci accessions in a two-dimensional plot using GenAlex version 6.5.1. The PCoA of the 80 accessions of cambuci based on the ISSR marker showed the existence of considerable genetic diversity among them (Figure 2).

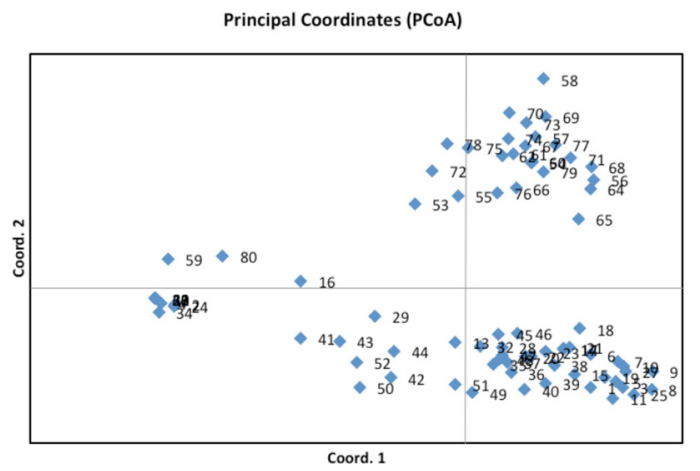

Figure 2. Principal coordinate analysis of the 80 cambuci (Campomanesia phaea) accessions using the data produced by the ISSR molecular marker.

The 80 accessions can be grouped into three clusters based on the PCoA (Figure 2), where the small group of accessions is separate and located on the left side of the graph and the two large groups are the right side of the graph. Based on the PCoA, the first two principal coordinates explain about $35 \%$ of the total variation. The grouping pattern observed in the PCoA is in accordance with the collection locations indicated by the gene bank managers. In order to support the PCoA analysis, another multivariate discriminant analysis was also performed using the R package adegenet DAPC. It produced similar groups, corroborating and confirming the results of the PCoA (Figure 3).

Bayesian model-based clustering analysis, which was performed using Structure software, grouped the 80 accessions into two principal clusters $(K=2)$ (Figure 4) with some accessions having mixed genetic makeup from the two groups.

Genetics and Molecular Research 15 (4): gmr15049134 


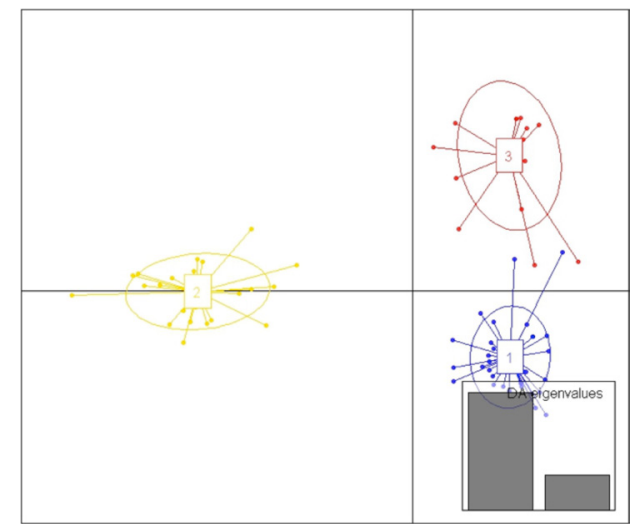

Figure 3. Discriminant analysis of the 80 cambuci (Campomanesia phaea) accessions performed with the adegenet DAPC package of $\mathrm{R}$, which formed three cluster groups.

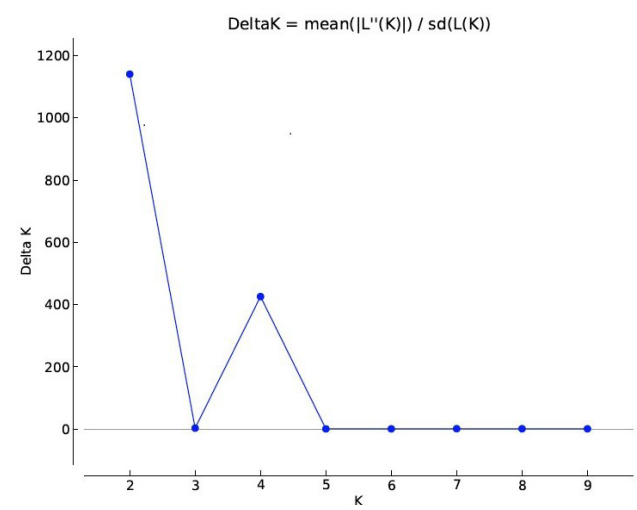

Figure 4. Appropriate group numbers (k) produced according the method proposed by Evanno et al. (2005) using the Structure Harvester program.

Even if the appropriate number of clusters defined based on this method was $\mathrm{k}=2$, some accessions showed some type of admixture from each group (Figure 5).

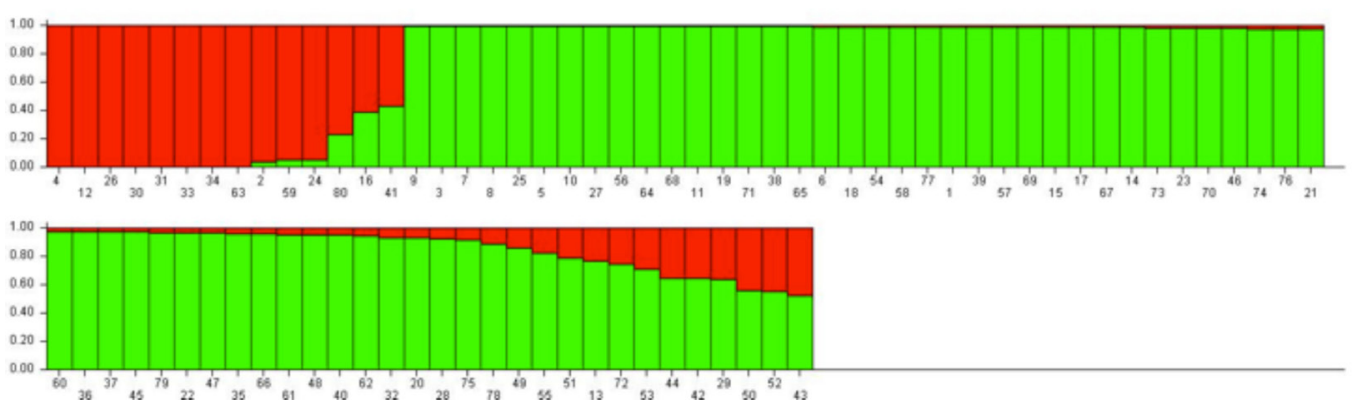

Figure 5. Bar graph showing the membership coefficient of an individual cambuci (Campomanesia phaea) accession in its respective groups as produced by the Structure software $(K=2)$.

Genetics and Molecular Research 15 (4): gmr15049134 
In the bar graph of the individual accessions (Figure 5), most of the accessions are grouped in cluster II (green), and only 12 accessions are grouped in cluster I (red). Most of the accessions were grouped based on a membership coefficient (q) of greater than $80 \%$, the appropriate cut-off value recommended by Pritchard et al. (2000). The grouping pattern produced by Structure clustering analysis showed only a small number of accessions in group I (red, 12), with most of the genotypes clustered in group II (green). This grouping pattern is in agreement with the results of the PCoA, since the same genotypes were grouped in the same clusters with Bayesian model-based clustering as with PCoA (Figures 2 and 5). The accessions in group I (red) in Structure clustering are located at the far left corner of the PCoA, whereas the accessions in group II (green) are located on the right side of the PCoA (Figure 2). Those accessions with high admixture in Figure 5 are located in the center of the PCoA graph. In summary, the two methods of clustering produced similar grouping patterns in this study. In addition, the two principal groups formed using the two clustering methods showed that these accessions were likely collected from the two principal regions of the Atlantic Forest (Serra do Mar and Serra da Mantiqueira), as suggested by the gene bank managers.

\section{DISCUSSION}

\section{ISSR marker analysis}

The 13 ISSR primers used in this study were able to detect considerable genetic diversity among cambuci accessions. ISSR markers have been used to study the population structure of Myrtaceae species by various authors. Brandão et al. (2011) used ISSR markers to study Myrtaceae species and observed seven to eleven polymorphic loci per primer, similar to the results of our study.

In our study, most of the ISSR primers used produced high PIC values $(>0.4)$, thus demonstrating their efficiency at discriminating and investigating the genetic diversity among cambuci accessions. The efficiency of ISSR markers for studying genetic diversity and population structure has also been reported by Kayis et al. (2010). Similar to our study, they observed strong positive correlation among the PIC values and MRP of the primers. This showed that these two parameters can be used as selection criteria for ISSR primers to study the genetic diversity and population structure of a given species. The only disadvantage observed with the use of the ISSR markers is the necessity of realizing two independent amplifications for each primer, which requires time and resources. However, this step is an important one, since it ensures the reproducibility of the primers and ensures the quality of the study results.

\section{Genetic diversity and population structure analysis among cambuci accessions}

In general, the ISSR molecular markers showed low to medium genetic diversity between cambuci accessions. The low genetic diversity reported in this study was found even when the genetic material was collected from the center of diversity for the species. This could be due to an inappropriate collection strategy including only accessions with similar genetic background. Similar to our study, ISSR markers have been employed to investigate the genetic diversity of various species within the family Myrtaceae. Ballesta et al. (2015) used

Genetics and Molecular Research 15 (4): gmr15049134 
ISSR markers to study genetic diversity in populations of Eucalyptus cladocalyx and found low genetic diversity among the studied genotypes. In contrast, Hue et al. (2015) used ISSR markers to investigate genetic diversity in Rhodomyrtus tomentosa and observed a high level of genetic diversity.

PCoA (Figure 2) classified the 80 cambuci accessions into three groups, whereas Bayesian-based clustering analysis (Figures 4 and 5) clustered them into two groups. The difference in the grouping pattern of the two methods of clustering may be attributed to the difference in statistical properties between them. More precisely, it may be due to the different principles adopted in each technique, which shows the importance of exploring different methods of analysis to confirm the veracity of the results. Even though the Bayesian-based clustering analysis grouped the accessions into two groups, in reality, there are some accessions that combine the two genetic backgrounds; these are considered the third group in the PCoA and are located in the center of the graph (Figure 2).

The highest membership coefficient value (above 90\%) presented by each accession (Figure 5) shows strong similarity within the group. This indicates the duplication of some accessions in the gene bank. In addition, this result supports the hypothesis of the gene bank managers that these accessions were probably collected from the two principal regions of the Atlantic Forest (Serra do Mar and Serra da Mantiqueira). The small number of cluster groups formed using the PCoA and structure clustering analysis indicates a problem in the sampling process during collection. Since this species is native to the Atlantic Forest, and this is considered the center of diversity, we should expect a high level of genetic variability among the accessions in this study. This highlights the importance of planning new collection strategies in the future to ensure maximum genetic variability in cambuci accession samples. According to Calaça and Dias (2010), the low genetic diversity in the Atlantic Forest is due to rapid fragmentation and agricultural expansion in the region. Environmental fragmentation erodes the neutral and adaptive genetic diversity in a population and causes reductions in population size and interpolation connectivity (Johansson et al., 2007). This was also observed in our study, with the low genetic exchange among the accessions in different groups likely a result of the lack of forest corridors among these populations.

Dixo et al. (2009) reported that the effect of fragmentation can be strong if fragment size is small because it can reduce population size and result in the extinction of the species under consideration. Therefore, the results reported here demonstrate the importance of urgent implementation of conservation activities to preserve the cambuci species.

Similarly, a general review report on the impact of agricultural expansion on genetic diversity in tropical and subtropical regions of the world by Laurance et al. (2014) showed the impact of agricultural activity expansion in tropical forests, including the Atlantic Forest in Brazil, where cambuci is found. It also highlighted the loss of the genetic diversity in the plant and animal species reported in this region.

Ribeiro et al. (2009) reported that the alarming rate of fragmentation of Atlantic Forest in Brazil has resulted in high genetic fixation among the populations of species in the forest. The authors also found a lack of conservation strategies by the organizations responsible for this important biodiversity. This biome harbors many important species like those that belong to the family Myrtaceae that have economic and social value to the local community. Our report also supported this finding, since most of the accessions were clustered in two major groups, which is not expected for accessions collected in their natural habitat.

In other species of Myrtaceae from Brazil, Telles et al. (2003) confirmed a low degree

Genetics and Molecular Research 15 (4): gmr15049134 
of differentiation due to the lack of forest corridors between populations to permit the flow of genetic material from one part of the region to other. In our study, we observed a high fixation index within the cluster groups that supports this conclusion.

Thus, to facilitate genetic exchange and recover the genetic diversity of cambuci, it is necessary to create conservation activities that can facilitate genetic exchange among the populations of Serra da Mantiqueira and Serra do Mar. These two populations should also be the focus of national conservation and breeding programs, because they contain rich genetic diversity that can ensure genetic gain and future breeding success for this species.

\section{Conflicts of interest}

The authors declare no conflict of interest.

\section{ACKNOWLEDGMENTS}

The authors would like to thank Coordenação de Aperfeiçoamento de Pessoal de Nível Superior (CAPES), Conselho Nacional de Desenvolvimento Científico e Tecnológico (CNPq), and Fundação de Amparo à Pesquisa do Estado de Minas Gerais (FAPEMIG) for the project funding and scholarships.

\section{REFERENCES}

Aguiar AP, Chiarello AG, Mendes SL and Matos EM (2003). The Central and Serra do Mar Corridors in the Atlantic Forest of Brazil. In: Galindo-Leal C, Câmara IB. The Atlantic Forest of South America: Biodiversity Status, Threats, and Outlook. Island Press, Washington.

Alizadeh M, Singh SK, Jhang T and Sharma TR (2008). Inter Simple Sequence Repeat Analysis to Confirm Genetic Stability of Micropropagated Plantlets in Three Grape (Vitis spp) Rootstock Genotypes. J. Plant Biochem. Biotechnol. 17: 77-80. http://dx.doi.org/10.1007/BF03263264

Amnon L, Claude ET, Newman M, Reddy OUK, et al. (2004). ISSR and AFLP markers differ among American watermelon cultivars with limited genetic diversity. J. Am. Soc. Hortic. Sci. 129: 553-558.

Anderson JA, Churchill GA, Autrique JE, Tanksley SD, et al. (1993). Optimizing parental selection for genetic linkage maps. Genome 36: 181-186. http://dx.doi.org/10.1139/g93-024

Ballesta P, Mora F, Contreras Soto RI, Ruiz E, et al. (2015). Analysis of the genetic diversity of Eucalyptus cladocalyx (sugar gum) using ISSR markers. Acta Sci. Agron. 37: 133-140. http://dx.doi.org/10.4025/actasciagron.v37i2.19307

Basha SD and Sujatha M (2007). Inter and intra-population variability of Jatropha curcas (L.) characterized by RAPD and ISSR markers and development of population-specific SCAR markers. Euphytica 156: 375-386. http://dx.doi. org/10.1007/s10681-007-9387-5

Bianchini FG, Balbi RV, Pio R, Silva DF, et al. (2016). Caracterização morfológica e química dos frutos de cambucizeiro. Bragantia 75: 10-18. http://dx.doi.org/10.1590/1678-4499.096

Brandão MM, Almeida VF and Carvalho D (2011). Estrutura genética em microescala espacial de Myrcia splendens (Myrtaceae). Rev. Arvore 35: 957-964. http://dx.doi.org/10.1590/S0100-67622011000600001

Calaça M and Dias WA (2010). The modernisation of the field in the cerrado and transformations socio-spatial on Goiás. Camp. Territorio: Rev. Geog. Agraria 5: 312-332.

Carnaval AC, Hickerson MJ, Haddad CFB, Rodrigues MT, et al. (2009). Stability predicts genetic diversity in the Brazilian Atlantic forest hotspot. Science 323: 785-789. http://dx.doi.org/10.1126/science.1166955

Casu M, Maltagliati F, Cossu P, Lai T, et al. (2005). Fine-grained spatial genetic structure in the bivalve Gemma gemma from Maine and Virginia (USA), as revealed by Inter-Simple Sequence Repeat markers. J. Exp. Mar. Biol. Ecol. 325: 46-54. http://dx.doi.org/10.1016/j.jembe.2005.04.020

Cheong MLS and Ranghoo-Sanmukhiya VM (2013). Phylogeny of Syzygium Species using Morphological, RAPD and ISSR Markers. Int. J. Agric. Biol. 15: 511-526.

Danner MA, Sasso SAZ, Bittencourt JVM, Citadin I, et al. (2011). Proposta de protocolo para extração de DNA de jabuticabeira. Cienc. Florest. 21: 363-367. http://dx.doi.org/10.5902/198050983241

Genetics and Molecular Research 15 (4): gmr15049134 
Dhanorkar VM, Tamhankar SA, Patil SG and Rao VS (2005). ISSR-PCR for assessment of genetic relationships among grape varieties cultivated in India. Vitis 44: 127-131.

Dixo M, Metzger JP, Morgante JS and Zamudio KR (2009). Habitat fragmentation reduces genetic diversity and connectivity among toad populations in the Brazilian Atlantic Coastal Forest. Biol. Conserv. 142: 1560-1569. http:// dx.doi.org/10.1016/j.biocon.2008.11.016

Earl DA and vonHoldt BM (2012). Structure Harvester: a website and program for visualizing STRUCTURE output and implementing the Evanno method. Conserv. Genet. Resour. 4: 359-361. http://dx.doi.org/10.1007/s12686-011-9548-7

Evanno G, Regnaut S and Goudet J (2005). Detecting the number of clusters of individuals using the software STRUCTURE: a simulation study. Mol. Ecol. 14: 2611-2620. http://dx.doi.org/10.1111/j.1365-294X.2005.02553.x

Hue TS, Abdullah TL, Abdullah NAP and Sinniah UR (2015). Genetic variation in Rhodomyrtus tomentosa (Kemunting) populations from Malaysia as revealed by inter-simple sequence repeat markers. Genet. Mol. Res. 14: 16827-16839. http://dx.doi.org/10.4238/2015.December.14.10

Jimenez HJ, Martins LSS, Montarroyos AVV, Silva Junior JF, et al. (2015). Genetic diversity of the Neotropical tree Hancornia speciosa Gomes in natural populations in Northeastern Brazil. Genet. Mol. Res. 14: 17749-17757.http:// dx.doi.org/10.4238/2015.December.21.48

Johansson M, Primmer CR and Merilä J (2007). Does habitat fragmentation reduce fitness and adaptability? A case study of the common frog (Rana temporaria). Mol. Ecol. 16: 2693-2700. http://dx.doi.org/10.1111/j.1365294X.2007.03357.X

Jombart T (2008). adegenet: a R package for the multivariate analysis of genetic markers. Bioinformatics 24: 1403-1405. http://dx.doi.org/10.1093/bioinformatics/btn129

Kawasaki ML and Landrum LR (1997). A rare and potentially economic fruit of Brazil: cambuci, Campomanesia phaea (Myrtaceae). Econ. Bot. 51: 403-405. http://dx.doi.org/10.1007/BF02861053

Kayis SA, Hakki EE and Pinarkara E (2010). Comparison of effectiveness of ISSR and RAPD markers in genetic characterization of seized marijuana (Cannabis sativa L.) in Turkey. Afr. J. Agric. Res. 5: 2925-2933.

Laurance WF, Sayer J and Cassman KG (2014). Agricultural expansion and its impacts on tropical nature. Trends Ecol. Evol. (Amst.) 29: 107-116. http://dx.doi.org/10.1016/j.tree.2013.12.001

Lima DF, Mauad AVS, Pereira VSP, Smidt EC, et al. (2015). Species boundaries inferred from ISSR markers in the Myrcia laruotteana complex (Myrtaceae). Plant Syst. Evol. 301: 353-363. http://dx.doi.org/10.1007/s00606-014-1078-9

Lorenzi H, Bacher L, Lacerda M and Sartori S (2006). Frutas brasileiras e exóticas cultivadas (de consumo in natura). Instituto Plantarum de Estudos da Flora, São Paulo.

Martins-Lopes P, Lima-Brito J, Gomes S, Meirinhos J, et al. (2007). RAPD and ISSR molecular markers in Olea europaea L.: Genetic variability and molecular cultivar identification. Genet. Resour. Crop Evol. 54: 117-128. http://dx.doi. org/10.1007/s10722-005-2640-7

Ministry of Environment (2016). Announcing Ministry of Environment Web. 2016: 10.

Moraes Filho RM, Bonifácio-Anacleto F and Alzate-Marin AL (2015). Fragmentation effects and genetic diversity of the key semidecidual forest species Metrodorea nigra in Southwestern Brazil. Genet. Mol. Res. 14: 3509-3524. http:// dx.doi.org/10.4238/2015.April.15.15

Moreno S, Martin JP and Ortiz JM (1998). Inter simple sequence repeats PCR for characterization of closely related grapevine germplasm. Euphytica 101: 117-125. http://dx.doi.org/10.1023/A:1018379805873

Nascimento MA, Batalha-Filho H, Waldschmidt AM, Tavares MG, et al. (2010). Variation and genetic structure of Melipona quadrifasciata Lepeletier (Hymenoptera, Apidae) populations based on ISSR pattern. Genet. Mol. Biol. 33: 394-397. http://dx.doi.org/10.1590/S1415-47572010005000052

Nunes CF, Ferreira JL, Fernandes MCN, Breves SS, et al. (2011). An improved method for genomic DNA extraction from strawberry leaves. Cienc. Rural 41: 1383-1389. http://dx.doi.org/10.1590/S0103-84782011000800014

Peakall R and Smouse PE (2006). GenAlEx 6: genetic analysis in excel, population genetic software for teaching and research. Mol. Ecol. Notes 6: 288-295. http://dx.doi.org/10.1111/j.1471-8286.2005.01155.x

Pritchard JK, Stephens M and Donnelly P (2000). Inference of population structure using multilocus genotype data. Genetics 155: 945-959.

Ribeiro MC, Metzger JP, Martensen AC, Ponzoni FJ, et al. (2009). The Brazilian Atlantic Forest: How much is left, and how is the remaining forest distributed? Implications for conservation. Biol. Conserv. 142: 1141-1153. http://dx.doi. org/10.1016/j.biocon.2009.02.021

Reyes-Alemán JC, Valadez-Moctezuma E and Barrientos-Priego AF (2016). Assessment of genetic relationship in Persea spp by traditional molecular markers. Genet. Mol. Res. 15: 1502735. http://dx.doi.org/10.4238/gmr.15027359

Le Saout S, Hoffmann M, Shi Y, Hughes A, et al. (2013). Conservation. Protected areas and effective biodiversity conservation. Science 342: 803-805. http://dx.doi.org/10.1126/science.1239268

Genetics and Molecular Research 15 (4): gmr15049134 
Telles MPC, Coelho ASG, Chaves LJ, Diniz-Filho JAF, et al. (2003). Genetic diversity and population structure of Eugenia dysenterica DC ("cagaiteira" - Myrtaceae) in Central Brazil: Spatial analysis and implications for conservation and management. Conserv. Genet. 4: 685-695. http://dx.doi.org/10.1023/B:COGE.0000006124.55109.5e

Varshney RK, Graner A and Sorrells ME (2005). Genic microsatellite markers in plants: features and applications. Trends Biotechnol. 23: 48-55.http://dx.doi.org/10.1016/j.tibtech.2004.11.005

Yeh FC and Boyle TJB (1997). Population genetic analysis of co-dominant and dominant markers and quantitative traits. Belg. J. Bot. 29: 1.

Genetics and Molecular Research 15 (4): gmr15049134 